\title{
Analysis and Proposals for Improving Knowledge and Skills in Engineering Aimed at Reducing Unemployment
}

\author{
Dominika CRNJAC MILIĆ, Goran MARTINOVIĆ, Ivanka FERČEC
}

\begin{abstract}
The aim of this paper is to assess the readiness of engineering students to enter the labour market and to make proposals for improving their knowledge and skills. Our research is based on the assumption that smart economic growth should be based on interdisciplinary knowledge including ICT, communication in foreign languages and economic knowledge. Results of the study conducted on a sample of 153 final-year engineering students point to the necessity of changing educational needs, and to the knowledge and skills desirable in the labour market, and this is supported by the respondents' opinion on the conditions for knowledge acquisition at their tertiary education institutions but also by their willingness to acquire the necessary knowledge.
\end{abstract}

Keywords: economic knowledge; foreign language; higher education; ICT; interdisciplinarity; labour market

\section{INTRODUCTION}

With the accession of the Republic of Croatia to the EU, higher education institutions have opened their doors to many students across Europe, which has in turn imposed a new need for improvement of their expert knowledge, as well as language and communication skills. In addition to the possibility of studying abroad, students in the Republic of Croatia also have the opportunity to interact with foreign students staying at institutions in their home country. Among other advantages, such as language training and exchange of experience with people from culturally diverse backgrounds, there is a need for a greater focus on learning to make high-quality interaction possible, and also to enable greater competitiveness in the labour market [3].

On the other hand, faculties are likely to obtain financial support from EU funds for development and advancement that the state as the main funder can provide only partially or not at all. Various courses and modular teaching offer the possibility of funding from the faculty's own resources, because there is often either no need or not enough time to teach students throughout their study programmes.

This paper assesses the readiness of engineering students to enter the labour market. The hypothesis in this paper is that economic growth should be based on interdisciplinary knowledge, the use of information and communication technologies, communication in a foreign language in a business environment, and a broad knowledge of economics, by means of which it is possible to convert innovative ideas into new products and services. The study was conducted on a sample of 153 final-year graduate-level engineering students. Data analysis is based on descriptive statistics indicators. The paper analyses the key issues in the evaluation of the current situation and the development of guidelines for Croatian higher education according to the needs of the labour market. The results can also support the process of managing the development of this system.

The paper is organised as follows. In Section 2, we present an analytical approach those points to the necessity of changing educational needs. Section 3 explains the knowledge and skills desirable in the labour market, both supported by the respondents' opinion on the conditions for knowledge acquisition at tertiary education institutions they will graduate from, but also by their willingness to acquire the necessary knowledge. Section 4 describes the method of survey data collection, while Section 5 gives statistical analysis of survey results. Finally, the conclusions are presented in Section 6.

\section{CHANGING EDUCATIONAL NEEDS}

The increasing complexity of business environments has resulted in the need for both active participation of economic operators, hence also individual employees, in creating change, and a fast response and the quick adaptation to new business conditions. Much attention has been focused recently on knowledge, creativity and skills of employees who are "different from others". Intellectual capital became increasingly important in the early nineties of the $20^{\text {th }}$ century. It has become a topic of many scientific studies, but it has also aroused considerable interest among business practitioners.

We are becoming more and more aware of the fact that the economy depends on knowledge, and the globality trend brings forth a constant struggle with uncertainty and market changes. In the context of reducing unemployment, the question constantly arises as to what knowledge and skills complex business systems require of their current and future employees. Higher levels and different combinations of competences and qualifications required by Croatian employers as well as compliance of education and labour market needs in the context of Croatia are the issues studied in a 2014 survey by $[5]$.

Human resources and human resource management in the contemporary situation are an important key factor for each company to succeed in business, as in [7] and [22]. Thus, human resource management is becoming not only the most important business function, but also specific philosophy and an approach to management that consider people to be the most important potential of this key strategic and competitive advantage.

Although at the present time information reaches the required destination quickly and easily, there seems to 
exist a certain gap in the implementation of the theory in practice and the necessary and fast integration of highly educated professionals specialised in certain fields into business environments. The economic sector has changed employment opportunities. Automation industry has advanced significantly and the service sector has enjoyed tremendous growth, particularly in the fields of telecommunications, information technology, etc. The traditional manufacturing facilities are continuously reducing the number of employees or closing down and their place in the labour market is increasingly occupied by the private sector, which tends to lean management. There are often companies that employ up to twenty people and belong to the service sector. High qualifications are often required for job vacancies in the industry sector. It is much more difficult for medium- and low-skilled persons to compete in the labour market. Spending an entire working career with the same company has become a myth, although according to research in [5], when asked about the main difference between younger and older employees in the Republic of Croatia, most of the employers agreed with the statement that "younger employees are more flexible and faster, while older employees are more experienced and more reliable". One employer explained further the difference between generations: "Older employees want a secure job until retirement, while young people want to gain some experience and then try to find a better job." Nevertheless, we can witness that jobs which are not too demanding in terms of expertise and high qualifications are being cut. Most employees today are increasingly aware of the fact that they constantly need to update their knowledge, because many jobs today require a higher level of qualifications than disappearing jobs or jobs that are completely neglected. The need for monitoring changes in the profession is no longer reserved only for employees in management positions in companies, but it has already become characteristic of operating activities that are paid less. Education is carried out through courses that employees are obligated to take and pass in a timely manner in order to keep their jobs [10].

In addition to technical skills closely related to the work employees do every day in the company, more attention is focused by employers on the development of individual employees in relation to the competences that have proved to be a condition of greater efficiency of individuals in their predestined role in the environment they work in, such as $[1,2,8,11,19,20]$ :

- initiative and consistency in work,

- written and oral communication skills, not only in the mother tongue, but also in a foreign language, predominantly English,

- innovation and creativity,

- orientation and commitment to service or product users,

- productive cooperation with business associates,

- leadership qualities, and

- tendency towards teamwork.

When it comes to engineering, many authors emphasise the importance of both written and oral communication skills. In [19], Patil stresses the importance of effective technical communication and claims that "the engineering students value technical subjects and underestimate the subject Communication Skills". On the other hand, in [20], Riemer claims that "a lack of sufficient communication skills serves only to undermine the image of the engineer". A recent report from Australia also confirms that employers generally do not take into consideration graduates with a degree only, but they need and look for graduates with excellent communication, decision-making and teamwork skills [20], which is actually in line with the aforementioned. In relation to these competences, according to recent research conducted by EduCentar portal, employers in the Republic of Croatia point out that older employees have much more expertise than their younger colleagues $(70 \%$ compared to 7\%). Accordingly, employers also believe that leadership skills of older employees are stronger compared to those under 30 years (53\% and 2\%).

Hence more and more companies realise that knowledge and continuous training of employees are much more necessary for their survival and growth than capital investment in new machinery and buildings. On the other hand, better employability prospects of highly educated persons have caused an increase in the number of students and the pressure exerted on higher education institutions in the sense that now even those who would, in more stable economic conditions, prefer to complete only their secondary school education want to study as well. In addition, there are often cases when those individuals who have been working in fear of losing their job want to get a degree as well. Increasing employability of persons holding a university degree in the Republic of Croatia was investigated by [16], and after that an upward trend was recorded [17]. There are a large number of new students admitted to higher education institutions, and the number of those who graduate is not small either, which results in increased competition and pressure on each vacancy.

By exploring the opinions and attitudes of final-year engineering students, i.e., future MEng degree holders, who will soon be drivers and carriers of economic growth and development, we would like to contribute to the advancement of knowledge and skills in engineering careers in order to reduce unemployment, primarily in the Republic of Croatia.

\section{KNOWLEDGE AND SKILLS DESIRABLE IN THE LABOUR MARKET}

The European Commission has identified communication in foreign languages and digital skills (traditional skills) and initiative and entrepreneurship (horizontal skills) as some of the key competences vital not only to personal growth and development, but also to ensuring employability in an increasingly competitive labour market.

Croatia's economy is slowly exiting recession and long-awaited economic growth is expected to increase the need for workers in engineering, especially in areas like civil engineering or mechatronics, which has recently recorded great interest. Knowledge and skills that are the prerequisites for success in the labour market in the field of ICT are broadly speaking good knowledge of current computer and communication environments, algorithmic 
techniques suitable for solving current problems, and knowledge and use of programming paradigms, languages, technologies and environments that offer appropriate software solutions.

According to the results of a survey carried out in 2014 on the needs and opportunities of ICT experts conducted within the framework of the e-Skills Initiative, $71 \%$ of employers expressed the need for and the interest in recruiting experts in the field of informatics and computer science, electrical engineering, civil engineering and mechatronics.

Compliance of education and the labour market needs is an unavoidable subject covering several areas. According to a survey of more than 50 employers and 250 job seekers that was conducted in Croatia by [5], there are increasingly higher levels and different combinations of competences and qualifications required in the labour market. For example, the competences possessed by younger employees refer to computer knowledge (75\% of younger employees compared to only $7 \%$ of older employees), foreign languages $(61 \%$ of younger employees and only 5\% of older employees) and new marketing knowledge (39\% of young employees, while older employees do not have this knowledge at all). Furthermore, employers believe it might be useful to introduce the following subjects into the national highschool curriculum: Communication and Presentation Skills (63\%), Computer Literacy (18\%) and Entrepreneurship (11\%). With regard to the (additional) investment in education, $59 \%$ of job seekers recognise that their qualifications are not enough to find a (better) job. $42 \%$ of them confirm that, while applying for a job, they have noticed that they lack the skills expected from candidates by employers. Job seekers are mostly aware of the fact that retraining would increase their chance of getting a (better) job, i.e., even $65 \%$ of respondents are ready to retrain, while $13 \%$ of them have already retrained. On the other hand, $26 \%$ of respondents are not willing to retrain at all. A good indicator might also be the fact that $80 \%$ of job seekers are ready to invest their own funds in their (additional) education.

\subsection{The Conditions for Knowledge Acquisition}

According to the Education, Science and Technology Strategy [18] and the Action Plan for the Internationalisation of Education for the period 20152016, one of the strategic objectives in higher education refers to the "internationalisation of higher education and its integration into the European and global higher education area", the aim of which is to increase the quality of the education system, as well as employability of pupils and students. It encourages inter alia incoming and outgoing mobility of students and teachers, the introduction of courses in foreign languages ("internationalisation at home") and joint study programmes with important European and international higher education institutions. These forms of education internationalisation are represented in a number of strategic documents of the European Union, particularly in the Council conclusions on a strategic framework for European cooperation in education and training [4].
It is well-known that globalisation directly influences industry requirements, which means that modern engineers, or as Riemer [19] says, global engineers, are expected not only to be proficient in their respective fields of specialisation but also to acquire some other skills which will make them competitive in these demanding global circumstances. As a result, in order to be competitive and successful in the global labour market, modern highly qualified engineers should possess high foreign language proficiency and well-developed communication skills (ideally in English). On the one hand, ESP (i.e., English for Specific Purposes) teachers are most frequently teachers of English for General Purposes, and on the other hand, "... the ESP teacher requires previous and additional training ... regarding the competence required on the part of the practitioner of ESP in handling materials related to the students' field... and ideally ESP teachers should have a twofold training in language and the content area of their students" [6], which may actually call for collaboration among the ESP practitioner and the content teacher. Strictly speaking, generally this may imply that "a deficiency in English language skills might be a major barrier to effective participation in the global economy" ([11, 21, 24]).

As the most widely spoken language around the world, English is considered to be a lingua franca (also known as bridge language, common language, trade language or vehicular language) in a wide variety of fields like engineering, medicine, business, aviation, entertainment, diplomacy, etc. Hence, it is most frequently referred to as a global language or the major medium of instruction, publishing and international negotiation. English is the language used for official communication (e.g. meetings, presentations, training, conferences, letters, documents, reports, etc.). Mastering the English language includes a number of related skills necessary for effective communication (e.g. presentation skills, negotiation skills, interpersonal skills) and generally speaking, communication skills are essential to everyone's professional growth. The globalisation process in general, the increased mobility of professionals, international projects and cross-cultural communication, have all made English the main language of communication for engineers. Knowledge of English is especially important for computer engineers and ICT experts, because in their daily work in software development and maintenance they use exclusively English. Accordingly, engineering education needs to stand up to the challenge of preparing new professionals with excellent English language skills ([11] and [20]).

On the other hand, although "there is a clear necessity for effective English communication skills for engineers in the current globalised environment" [20], multilingualism should not be confined to learning English only. In the European context, the importance of German (especially of German for Specific Purposes, cf. $[12,14,23])$ is indisputable. There are four Germanspeaking countries in Europe with diverse cultural, political, and economic traditions and approximately 101 million native speakers of German. Germany is among the leaders in computing, automobile industry, engineering, chemical and pharmaceutical industry. In the field of electrical engineering, Germany is the world's 
leader in renewable energy, i.e., about half of all photovoltaic cells and a third of all windmills are produced in Germany. Hence if proficiency in English is a must in the field of engineering, then speaking German is a big plus. Although German has been present in Croatia longer than English, although the Germans left a mark on the Croatian language and its dialects, and although there are political, economic and cultural ties with the Germanspeaking countries, some studies conducted in the Republic of Croatia have shown that unfortunately there is a slow but constant decline in the number of students learning German (for Specific Purposes) [9, 12, 13, 23]. But, on the other hand, German industry has traditionally been focused on science, technology and engineering. Currently, according to some data, Germany has the highest number of employed engineering workers and the second highest share of engineering workers among all employees in the European Union.

Our research results indicate that the respondents (i.e., students) are generally satisfied with the conditions for the acquisition of knowledge and skills at their higher education institutions (literature, the complexity of general and specialised courses, interdisciplinary courses, teaching in both general and technical English).

\subsection{Willingness of Students to Acquire the Necessary Knowledge}

In its communication entitled "Europe 2020: A European strategy for smart, sustainable and inclusive growth" [4], the European Commission gave some analyses and guidance to turn the EU into a highemployment economy which would ensure economic, social and territorial cohesion. The document stressed that Europe must increase the employment rate of the population, especially in the most peripheral parts of the EU Croatia also belongs to. Their analysis points to the fact that only two-thirds of the working population is currently employed, compared to $70 \%$ in the USA and Japan. The unemployment rate of young people is over $21 \%$ and there is a great risk that people who are not in contact with or are poorly attached to the world of work stop being competitive in the labour market. Their projections are that by 2020 additional 16 million jobs will require a university degree, while the demand for low skills will fall by 12 million jobs. Since according to their data, nearly 80 million people today have low or only basic skills and lifelong learning benefits mostly those who are more educated, there is a need for intensive work on this problem. The Commission advised that at national level, Member States must provide a sufficient number of science, mathematics and engineering graduates and focus their curricula on creativity, innovation and entrepreneurship.

Intellectual capital is becoming the main asset of any business organisation in the modern world and the most important source of competitive advantage. The difference in the success of organisations today lies in the quality of intellectual capital management. Therefore, the readiness of future and current employees for continuous improvement and intellectual advancement is important. The respondents of our study indicated their willingness to adapt to changes in their profession, but also to go abroad both for training and with the intention of staying there permanently, to participate in EU projects, to enrol in the postgraduate study programmes and lifelong learning courses, as well as the ability to connect and apply the acquired general and special knowledge to problem-solving practice. It is interesting to note that although the respondents are of the opinion that for employment and career advancement they need more than one foreign language, they do not consider knowledge of the German language relevant.

\section{DATA COLLECTION PROCESS}

The study was conducted by means of a written questionnaire filled in by 153 students at engineering faculties in Croatia. The survey was aimed at students enrolled in the last semester of their second, i.e., senior year of study with only a few exams before they complete their respective graduate study programmes and are awarded a Master of Engineering (MEng) degree in the fields of power engineering, IT, communications, electrical and mechanical engineering. They were asked to respond to 22 questions. They were also given the opportunity to make an open-ended comment at the end of the questionnaire. In order to determine the basic features of their responses, descriptive statistics were used in the analysis. As shown in Table 1, students' responses to the 16 questions were measured by a five-point Likert scale starting from 1 (strongly disagree) to 5 (strongly agree), while in the remaining 6 questions students had the opportunity to answer the question by yes or no.

In principle, the questionnaire examines the conditions referring to the acquisition of knowledge and skills during studies, assessment of students' ability to apply the acquired knowledge and to acquire new knowledge, and the willingness and desire to acquire new knowledge and skills in the fields of engineering and technology, business and foreign languages.

The aim of question 1 is to assess the availability of resources, i.e., teaching/learning materials and textbooks, because it is one of the basic prerequisites for acquiring knowledge and skills needed in the labour market. Question 2 allows students to assess their own ability to follow the trends in the profession, and the desire for and awareness of the need for lifelong learning, which is especially important in ICT technologies. In question 3, students are supposed to assess their desire to have some teaching activities carried out through collaboration with industry. Questions 4, 5 and 6 give students the opportunity to assess the complexity of fundamental and specialised courses within their study programmes and respective fields of specialisation. The level of students' own conceptual thinking, readiness for self-employment, understanding of business operations and related problems are assessed in questions 7, 8, 9 and 10 . Question 11 deals with the assessment of the ability to apply the acquired knowledge and skills in their future work. Questions 12, 13, 14, 15 and 16 deal with the students' readiness to go abroad for training and job seeking, to participate in EU projects, and to continue with their informal, formal, and postgraduate education, respectively. In question 17, students assess interdisciplinarity of courses in relation to their 
application in their future jobs. Questions 18 to 22 examine the importance of a foreign language for finding a job and doing the job successfully. The number of foreign languages a student speaks (spoken and written), the importance of languages for specific purposes, the importance of German, and students' satisfaction with the representation of listening, speaking, reading and writing skills in technical English classes during their studies are issues considered in these questions.

\section{RESULTS AND ANALYSIS}

Questionnaire results (see Tab. 1) show the opinion and assessment of survey respondents, i.e., engineering students. The basic features of their responses were analysed by using descriptive statistics. The mean values of given responses were calculated by the arithmetic mean, while measures of dispersion, i.e., the standard deviation and the coefficient of variation, were used as indicators of dispersion, i.e., a degree of variability in the data. Over half of the respondents $(55.92 \%)$ assessed the availability of learning resources during their studies by very good and $28.16 \%$ by excellent, as indicated by the mean value of 3.87 , a relatively low deviation from the mean $(0.88563+)$ and the coefficient of variation of $23 \%$. In question 2, the mean value of 3.80 , the largest representation of the score very good and the relatively high representation of the scores good and excellent indicate that students are independent in their work and enthusiastic about monitoring changes in the profession and lifelong learning. Assessment of the acceptability of student activities in conjunction with the practice and participation in projects reveals that students' opinions differ significantly despite the mean value of 3.15 , while it is clear from other data (standard deviation of 1.27 and the coefficient of variation of $40 \%$ ). In question 4 , the mean value of the level of complexity of fundamental courses within the respondents' study programmes is 3.20, with good (i.e., 3) and very good (i.e., 4) significantly above $40 \%$, while at the same time the share of other scores is very low. The standard deviation of 0.80 and the coefficient of variation of $25 \%$ indicate a low dispersion of allocated scores. According to results in relation to question 5 regarding the complexity of fundamental courses within the respondents' fields of specialisation, results very similar to question 4 can be seen (mean value 3.17, standard deviation 0.86 , coefficient of variation 27\%). Also, the level of complexity of specialised courses within the respondents' study programmes is assessed by the average score good (i.e., 3.26), again with both good (i.e., 3) and very good (i.e., 4) significantly above $40 \%$, whereas the deviation and the coefficient of variation are similar to the previous two questions ( 0.91 and $28 \%$ ). More than $50 \%$ of students believe that the level of their conceptual thinking in connecting general knowledge with the application in a specific situation to resolve practical and technical problems is very good. The average score of 2.93 refers to willingness to become self-employed (question 8), with the standard deviation of 1.13 and the coefficient of variation of $39 \%$, since in addition to the most frequent scores good (3) and very good (4), scores 2 (sufficient) and 5 (excellent) are represented equally by $15.39 \%$ each.
In question 9, respondents assessed the level of understanding of business operations by the mean value 3.00 , with 3 being the most common score (48.12\%). In addition to the score very good that is represented by $28.07 \%$, other scores have significantly lower shares, which are reflected by the standard deviation of 0.93 and a variation of $31 \%$. When asked to assess their awareness of potential profession-related problems that could arise in business organisations in the future, the respondents' average score was 3.10 , with the highest representation of the score $\operatorname{good}(39.23 \%)$, and a rather high proportion of very good (31.96\%). Other scores are much less common so that the standard deviation is 0.98 and the coefficient of variation of $32 \%$. Respondents assessed their own level of ability to apply expertise and skills acquired during their studies that will be used in their future jobs by the highest proportion of the score very good $(41.81 \%)$, but significant values can also be seen with good $(34.20 \%)$. Responses to question 12 indicate a high level of readiness (even 84.96\%) for training abroad. Also, a similar result $(85.71 \%)$ related to the respondents' willingness to go abroad for the purpose of seeking/finding a job within their field of study was obtained in question 13. In line with the aforementioned responses, we notice that their willingness to participate in EU projects is important (based upon grades very good and excellent, i.e., $31.40 \%$ and $37.19 \%$, respectively), resulting in the high mean value of 3.64. A relatively large dispersion is evident in the responses to question 15, in which respondents indicated their desire to participate in informal education at their higher education institution (through workshops, courses, professional development, various forms of continuing education, etc.) in order to keep up with changes in their profession. Nevertheless, the scores are distributed as follows: $3-21.15 \%, 4$ $40.53 \%$ and $5-27.53 \%$, which ultimately results in the mean value of 3.41. The importance of continuing formal education by enrolling in a $\mathrm{PhD}$ study programme offered by the higher education institution the respondents graduate from is assessed in question 16 by a lower average score of 2.87 , with all scores other than 1 being proportionally represented so that the standard deviation (1.21) and the coefficient of variation $(42 \%)$ are relatively high. More than 50\% of respondents assessed interdisciplinarity of courses for the purpose of linking the study programmes with practice by score 3 . However, the average score of 2.80 , the standard deviation of 0.98 and the coefficient of variation of $35 \%$ indicate that other scores, with the exception of 4 , remain relatively poorly represented. Question 18 that refers to whether knowledge of a foreign language is sufficient for respondents to be competitive in the labour market received almost equal percentage of affirmative and negative responses $(41.10 \%$ and $57.90 \%$, respectively). However, in the next question, when asked whether knowledge of one or more foreign languages is crucial to finding a job, $85 \%$ of respondents said "Yes". A high percentage of scores $4(45.74 \%)$ and 5 $(42.65 \%)$ in relation to question 20 shows that the vast majority of respondents are well aware of the fact that their knowledge of both a general foreign language and a (foreign) language for specific purposes is important for career advancement. In question $21,65.41 \%$ of respondents believe that knowledge of the German 
language would increase their competitiveness in the labour market. And finally, when asked in question 22 to assess whether they are satisfied with the representation of all four skills in (technical) English courses that are required for effective communication in their future job, $78.95 \%$ of respondents replied affirmatively.

Table 1 Results collected by a questionnaire

\begin{tabular}{|c|c|c|c|c|c|c|c|c|}
\hline \multirow{3}{*}{ Question } & & & Score & & & \multirow{3}{*}{ Mean value } & \multirow{3}{*}{$\begin{array}{l}\text { Standard } \\
\text { deviation }\end{array}$} & \multirow{3}{*}{$\begin{array}{c}\text { Coefficient of variation } \\
\text { in } \%\end{array}$} \\
\hline & 1 & 2 & 3 & 4 & 5 & & & \\
\hline & \multicolumn{5}{|c|}{ Distribution in \% } & & & \\
\hline 1 & 0.20 & 4.66 & 11.06 & 55.92 & 28.16 & 3.87 & 0.88 & 23 \\
\hline 2 & 0.20 & 2.37 & 24.31 & 47.43 & 25.69 & 3.80 & 0.80 & 21 \\
\hline 3 & 4.30 & 10.98 & 25.06 & 33.41 & 26.25 & 3.15 & 1.27 & 40 \\
\hline 4 & 0.71 & 9.39 & 42.25 & 44.13 & 3.52 & 3.20 & 0.80 & 25 \\
\hline 5 & 0.95 & 10.92 & 41.33 & 40.86 & 5.94 & 3.17 & 0.86 & 27 \\
\hline 6 & 1.85 & 5.54 & 42.9 & 41.57 & 8.08 & 3.26 & 0.91 & 28 \\
\hline 7 & 0.21 & 7.71 & 26.55 & 50.54 & 14.99 & 3.51 & 0.88 & 25 \\
\hline 8 & 4.10 & 15.39 & 35.38 & 29.74 & 15.39 & 2.93 & 1.13 & 39 \\
\hline 9 & 2.01 & 13.03 & 48.12 & 28.07 & 8.77 & 3.00 & 0.93 & 31 \\
\hline 10 & 1.45 & 14.04 & 39.23 & 31.96 & 13.32 & 3.10 & 0.98 & 32 \\
\hline 11 & 1.19 & 13.30 & 34.20 & 41.81 & 9.50 & 3.17 & 0.95 & 30 \\
\hline \multirow{2}{*}{ Question } & \multicolumn{3}{|c|}{$\mathbf{Y}$} & \multicolumn{3}{|c|}{$\mathbf{N}$} & & \\
\hline & \multicolumn{6}{|c|}{ Distribution in \% } & & \\
\hline 12 & \multicolumn{3}{|c|}{84.96} & \multicolumn{3}{|c|}{15.04} & & \\
\hline 13 & \multicolumn{3}{|c|}{85.71} & \multicolumn{3}{|c|}{14.29} & & \\
\hline \multirow{3}{*}{ Question } & & & Score & & & \multirow{3}{*}{ Mean value } & \multirow{3}{*}{$\begin{array}{l}\text { Standard } \\
\text { deviation }\end{array}$} & \multirow{3}{*}{$\begin{array}{c}\text { Coefficient of variation } \\
\text { in } \%\end{array}$} \\
\hline & 1 & 2 & 3 & 4 & 5 & & & \\
\hline & \multicolumn{5}{|c|}{ Distribution in \% } & & & \\
\hline 14 & 1.23 & 5.37 & 24.79 & 31.40 & 37.19 & 3.64 & 1.11 & 31 \\
\hline 15 & 2.42 & 8.37 & 21.15 & 40.53 & 27.53 & 3.41 & 1.18 & 35 \\
\hline 16 & 5.23 & 18.33 & 25.13 & 35.60 & 15.71 & 2.87 & 1.21 & 42 \\
\hline 17 & 4.30 & 14.51 & 50.81 & 23.66 & 6.72 & 2.80 & 0.98 & 35 \\
\hline \multirow{2}{*}{ Question } & \multicolumn{3}{|c|}{$\mathbf{Y}$} & \multicolumn{3}{|c|}{$\mathbf{N}$} & & \\
\hline & \multicolumn{6}{|c|}{ Distribution in $\%$} & & \\
\hline 18 & \multicolumn{3}{|c|}{42.10} & \multicolumn{3}{|c|}{57.90} & & \\
\hline 19 & \multicolumn{3}{|c|}{85} & \multicolumn{3}{|c|}{15} & & \\
\hline & & & Score & & & & & \\
\hline Question & 1 & 2 & 3 & 4 & 5 & Mean value & Standard & Coemcient or variation \\
\hline & & Dist & ibution & in \% & & & & \\
\hline 20 & 0.00 & 1.81 & 9.80 & 45.74 & 42.65 & 4.14 & 0.79 & 19 \\
\hline Ouration & & $\mathbf{Y}$ & & & Y & & & \\
\hline Question & & & Dist & bution & $\%$ & & & \\
\hline 21 & & 65.41 & & & 34. & & & \\
\hline 22 & & 78.95 & & & 21. & & & \\
\hline
\end{tabular}

\section{CONCLUSION}

The habitual and sufficiently regular use of information and communication technologies is not typical of the Republic of Croatia as part of the peripheral region of the European Union, and some parts of society are unenthusiastic about innovation that may prevent them from entering the market and the business environment. Investment in education and technology would have a positive impact on traditional sectors, rural areas, and high-quality service economy. According to [15], human capital is the main tool for achieving competitive advantages not only in the national but also in the global market. Education and training must become a lifelong process, because it is conditioned by the constant pressure of competition.

Leading companies today are increasingly recognising that investments in education and training of employees are more important than capital investment in the construction of the plant, because an increase in the level of education increases employment opportunities. The new era poses new challenges and requires not only new knowledge, but also new people who will be able to respond to these challenges. The optimal combination of human, social and organisational capital is a key to business success and value maximisation, provided that there is also a constant increase in intellectual capital of an organisation. An analytical approach in this paper gives an introduction to the attitude of engineering students towards the labour market, i.e., the assessment of their readiness to enter the labour market. This paper is interdisciplinary and as such, it outlines the problem of employment from many aspects, but the focus was on the crucial knowledge in the fields of IT, economics and foreign languages. The aim of this research was to point out the necessity of bringing the theory and practice closer by means of certain changes that should facilitate the entry of students into the business world. Continuous structural changes in higher education, especially at engineering universities, should be done in small steps. Theoretical knowledge in various fields that students gain during their education must not be neglected in favour of the practice, but still senior students should get involved in business organisations before completing their 
university education, which would facilitate their transition to the business world, securing them at the same time competitiveness in the labour market. Our research results indicate that students are not fully aware of the importance of knowledge of foreign languages, especially German, which is important for engineering professions. We have noticed that they are not willing to participate in projects and write their Bachelor/Master theses in cooperation with companies, which contradicts their opinions expressed in the comments at the end of the questionnaire where they mostly emphasised their desire to do their practical training in the companies in the region. Respondents are mostly satisfied with the conditions at higher education institutions they study at, but the results do indicate that there is room for improvement in various aspects. A devastating result refers to the question of going abroad in terms of finding a job and remaining in countries outside their home country.

(Foreign) Languages for specific purposes at our engineering faculties should have better status: their values should be appreciated (especially of technical English) for the purpose of professional involvement of our young experts in professional circles in Europe and the world at large, and their importance should be encouraged in the sense that learning a language for specific purpose cannot be reduced to an optional course for which in some schools there is even no full-time lecturer (this particularly holds for German).

According to projections of economic analysts, the ICT sector will look for an increasing number of experts, because everything points to the growing export potential in this area given that this is about creating high-added value products. The need to develop this area of activity in the economy of a country is therefore very important. It is necessary to keep any potential employee and do not encourage their wish to go abroad. It is also important to focus the next generation of students on this type of study and the acquisition of knowledge and skills described in this paper in order to have the portfolio of future economy holder grow.

Engineering students' knowledge of economics should be expanded and they should be more involved into practical problem solving during their studies in order to bridge the gap between theory and practice, but also to reduce their fear of self-employment and accepting complex challenges awaiting them in the labour market.

The companies should be more likely to lend a hand to educational institutions and encourage students to do practical training there, as well as to try to offer them certain jobs after graduation. After this research, we believe that only such synergy can guarantee success.

\section{REFERENCES}

[1] Bahtijarević-Šiber, F. (1998). Informacijska tehnologija i upravljanje ljudskim potencijalima. Slobodno poduzetništvo, 5(7), 121-130.

[2] Bahtijarević-Šiber, F. (2014). Strateški menadžment ljudskih potencijala: suvremeni trendovi i izazovi. Školska knjiga, Zagreb.

[3] Crnjac Milić, D., Martinović, G. \& Ferčec, I. (2007) Analysis of desirable changes in engineering education in the context of university education reform. Tehnički vjesnik-Technical Gazette, 14(3/4), 31-36.

[4] Europe 2020: A European strategy for smart, sustainable and inclusive growth, 03.03.2010., $\operatorname{COM}(2010) 2020$. http://eur-lex.europa.eu/legal-content/EN/TXT/PDF/?uri= CELEX:52010DC2020\& from $=\mathrm{en}(24.02 .2016$.

[5] EduCentar Portal. http://educentar.net/Vijest/11828/90poslodavaca-spremno-je-ulagati-u-pocetnike/. (24.02. 2016).

[6] Esteban Almagro, A. \& Martos Vallejo, M. C. (2002). A Case Study of Collabouration among the ESP Practitioner, the Content Teacher, and the Students. Revista Alicantina de Estudios Ingleses, 15(7), 7-21. https://doi.org/10.14198/raei.2002.15.01

[7] Goić, S. (1998). Suvremeni trendovi u organizaciji upravljanja ljudskim resursima. Sveučilište u Splitu, Ekonomski fakultet Split, Split.

[8] Hüneburg, K. (2013). English for Science and Technology in the German Technical Industry - A Needs Analysis. Minnesota State University, Mankato.

[9] Kordić, Lj. \& Mujić, N. (2013). Strani jezik u funkciji pravne struke: istraživanje stavova djelatnih pravnika i studenata prava. Pravni vjesnik, 19(3-4), 57-78.

[10] Kurek, S. \& Rachwal, T. (2011). Development of entrepreneurship in ageing populations of the European Union. Procedia - Social and Behavioral Sciences, 19, 397405. https://doi.org/10.1016/j.sbspro.2011.05.147

[11] Liermann-Zeljak, Y. \& Ferčec, I. (2015). The Importance of English in the Education of Electrical Engineers - Vistas of English for Specific Purposes / Stojković, Nadežda (ed.). Newcastle upon Tyne: Cambridge Scholars Publishing, 199-212.

[12] Mesarić-Peras, M. (2010). Važnost učenja njemačkog jezika za studente menadžmenta turizma i sporta. Zbornik radova Međimurskog veleučilišta u Čakovcu, 1(1) 34-40.

[13] Mesarić-Peras, M. \& Knok, Ž. (2010). Njemački jezik u edukaciji studenata menadžmenta turizma i sporta. 1 . hrvatski znanstveno stručni skup o menadžmentu u turizmu i sportu: zbornik radova, Čakovec, 239-243.

[14] Moravcová, L. \& Mad’arová, L. (2013). Teaching English and German for Specific Purposes to Agricultural Engineers as a Path to Better Career Opportunities on the Foodstuff Market. Journal of Central European Agriculture, 14(3), 1220-1231.

[15] Noe, R. et al. (2006). Menadžment ljudskih potencijala. Zagreb, Mate d.o.o.

[16] Obadić, A. (2009). Stanje na tržištu rada $i$ u sustavu obrazovanja RH u kontekstu pridruživanja Europskoj Uniji, CPI mjesečno izvješće. Zagreb, Centar za politološka istraživanja.

[17] Obadić, A. \& Majić, E. (2013). Analiza strukture nezaposlenosti visokoobrazovanih osoba $\mathrm{u}$ Republici Hrvatskoj i mjere za njezino smanjivanje. Poslovna izvrsnost, 7(2), 103-123

[18] Narodne Novine, No. 124/14. http://narodnenovine.nn.hr/default.aspx (23.01.2016).

[19] Patil, M. R. Importance of English Communication for Engineering Students from Rural Areas and Its Remedies, IOSR Journal of Mechanical and Civil Engineering. URL:www.iosrjournals.org/iosr-jmce/papers/sicete(civil)volume2/20.pdf (12.03.2016).

[20] Riemer, M. J. (2002). English and Communication Skills for the Global Engineer. Global Journal of Engineering Education, 6(1), 91-100.

[21] Šimunović, A. (2013). Motivacija studenata za učenje stranih jezika. Učenje za poduzetništvo, 3(2), 216-227.

[22] Šverko, B. (2012). Ljudski potencijali: usmjeravanje, odabir $i$ osposobljavanje. Hrvatska sveučilišna naklada, Zagreb. 
[23] Tepeš Golubić, L. \& Bajić, M. (2013). Opportunities in Learning a Foreign Language on the Example of a Specialist Engineering Programme. International Conference ICT for Language Learning / Florence, 386389.

[24] Vorholt, J. \& Harris, E. (2014). Entrepreneurship and Student Motivation. English Teaching Forum, 52(3), 30-36.

\section{Contact information:}

Dr. Dominika CRNJAC MILIĆ, Associate Professor

Faculty of Electrical Engineering, Computer Science and Information

Technology Osijek, Josip Juraj Strossmayer University of Osijek

Kneza Trpimira 2B, 31000 Osijek, Croatia

E-mail: dominika.crnjac@ferit.hr

\section{Dr. Goran MARTINOVIĆ, Full Professor}

Faculty of Electrical Engineering, Computer Science and Information

Technology Osijek, Josip Juraj Strossmayer University of Osijek

Kneza Trpimira 2B, 31000 Osijek, Croatia

E-mail: goran.martinovic@ferit.hr

\section{Ivanka FERČEC, MA, Senior Lecturer}

Faculty of Electrical Engineering, Computer Science and Information Technology Osijek, Josip Juraj Strossmayer University of Osijek

Kneza Trpimira 2B, 31000 Osijek, Croatia

E-mail: ivanka.fercec@ferit.hr 